\title{
The University Library: The Center of a University Education?
}

Patricia A. Frade

pat_frade@byu.edu

Allyson Washburn

allyson_washburn@byu.edu

Follow this and additional works at: https://scholarsarchive.byu.edu/facpub

Part of the Library and Information Science Commons

\section{Original Publication Citation}

Frade, P.A., Washburn, A. (26). The University Library: The Center of a University Education?

Portal: Library \& the Academy, 6(3), 327-346.

\section{BYU ScholarsArchive Citation}

Frade, Patricia A. and Washburn, Allyson, "The University Library: The Center of a University Education?" (2006). Faculty Publications. 966.

https://scholarsarchive.byu.edu/facpub/966 accepted for inclusion in Faculty Publications by an authorized administrator of BYU ScholarsArchive. For more information, please contact ellen_amatangelo@byu.edu. 
The University Library: The Center of a University Education?

Patricia A. Frade and Allyson Washburn

Four decades ago, Chauncey Tinker asserted that the "three distinguishing marks of a university [were] — a group of students, a corps of instructors, and a collection of books; and of these three the most important [was] the collection of books." ${ }^{1}$ Even now, the role of the university library is often referred to as the keystone in a student's education. Maureen Brunsdale states that "academic libraries are often termed the 'heart of the campus,' not solely because of the collections... but also because of the services rendered by...various departments: i.e., reference, library instruction, interlibrary loan, etc. ${ }^{2}$ In 1962, however, L. Jolley concluded that "there is a general impression that students use libraries far less than they ought to." ${ }^{3}$ In fact, during 1997 , respondents to a University of Iowa study indicated that the main reasons that they came to the library were to

- $\quad$ study (72 percent),

- $\quad$ use the photocopier (70 percent),

- check out or borrow books, magazines, and journals (68 percent),

- $\quad$ use the instructional technology clusters (60 percent). ${ }^{4}$

However, are today's students really using our services? Indeed, questioning how students use the library is an important concern of university administrators because it factors into their decisions about requests for bigger budgets, additional space, and more personnel. During 2001-2002, a formal study was conducted jointly by Brigham Young 
University's Office of Planning and Assessment (OPA) and the Harold B. Lee Library (HBLL) to determine the value of the library to the university community. The study described in this paper was undertaken at a time when some experts were predicting the demise of the academic library, and university administrators were questioning the need for new building, budget, and personnel requests. This paper will present a description of the study and its results, a comparison of similar data collected two years later, and a description of two new student services — extended hours and an information commonsthat the library has implemented and their possible impact on library usage.

\section{Background}

The Harold B. Lee Library (HBLL) serves the Brigham Young University (BYU) campus community through one main library facility, which houses all disciplines. One branch library, the Howard W. Hunter Law Library, serves the law school. The Lee Library has a general reference area as well as 11 other subject-specific reference areas. During fall and winter semesters, the library general reference desk, periodicals reference desk, and circulation desk are usually open Monday through Friday from 7:00 a.m. to 12:00 midnight and Saturdays from 8:00 a.m. to 12:00 midnight. Other service areas are generally open from 8:00 a.m. to 10:00 p.m. The library has a seating capacity of 4,600. BYU's student enrollment is currently just under 30,000 during the fall and winter semesters, and there are approximately 5,000 faculty/staff personnel on campus. At the request of the Associate Academic Vice President's Office, the Office of Planning and Assessment (OPA) at BYU conducted a study from September 2001 to 
October 2002 to explore issues related to HBLL use and the library's value to the BYU community: "This study was initiated in order to provide administrators [with] data related to the maximal utilization of the library, with an eye toward serving the on-going and future library needs...as well as a focus on resource planning." ${ }^{5}$ Data collection sought to address issues related to (1) use of the library building, (2) use of the library collections, and (3) use of other library services.

\section{Literature Review}

A review of the literature suggests that, in the aggregate, the extent and frequency of college students' visits to their academic library followed a downward trend during the years 1997-2001.

Gate counts and circulation of traditional materials are falling at many college libraries across the country, as students find new study spaces in dorm rooms or apartments, coffee shops, or nearby bookstores. ... The burgeoning use of electronic databases has sent the buzz of library activity onto the Internet. The shift leaves many librarians and scholars wondering and worrying about the future of what has traditionally been the social and intellectual heart of campus. ...At the University of Idaho at Moscow, for example, door counts and book circulation have decreased by more than 20 percent since 1997, and reserve loans have plummeted by more than 60 percent. $^{6}$ 
Another example of this downward trend is given by Richard Albanese, who noted, "At Rhode Island College (RIC) in Providence, annual gate counts had declined steadily during the early years of the Internet, from 331,530 visitors in 1993-94 to a low of 240,948 in 1998-99."7

However, in the early part of the twenty-first century, the downward trend of library usage turned around nationally and, in some instances, rose dramatically. "But since 2000, gate counts at RIC have increased. Gate count for 2001-02 was back up to a healthy 282,501, its highest point since 1995-96. Figures thus far for 2002-03 put gate count on pace to rise again. Circulation figures... are also on the rise." 8

Helen H. Spalding, former president of the Association of College \& Research Libraries and dean of libraries, Portland State University, states, "We're finding our [daily visitor] counts are still going up. One of the reasons, I think, is that a lot of material online makes our collections more visible. People are getting more citations and realizing what they need is in the library." ${ }^{9}$ As further evidence of the increase in library usage, Brian Coutts, dean of libraries at Western Kentucky University, reported an increase in gate counts and circulation [through] some proactive steps to increase library usage. He further states that "today's campus library is more than just a place to get resources. It's a destination that supports new, technology-driven teaching, learning, and research patterns, offering everything from books to digital databases to a social space for students to gather." ${ }^{10}$ The research would indicate that while gate counts fell during the late 1990s, they are now rising again.

Methodology 
Three methods were used in collecting data for the OPA report including (1) circulation, re-shelving, and usage statistics, (2) an e-mail survey, and (3) naturalistic observations followed by interviews.

Circulation data, obtained from the HBLL databases, were connected to student and faculty demographic files from institutional databases. Other circulation and usage statistics were collected using on-going information reports generated by the HBLL. Re-shelving data are routinely collected from the Circulation Department and were included in the study. ...A survey concerning a) frequency of use and b) importance to students of some library services was sent electronically to 1,500 students who were selected using stratification by college and department. Of these students, 1,430 addresses were usable, and 1,010 completed the survey (response rate $=71$ percent) ${ }^{11}$

Using a 7 -point Likert scale $(1=$ once a semester or less; $7=$ several times a day $)$, students were asked how frequently they used specific library services. Similarly, for the importance of service use, students were asked to indicate using a 4-point Likert scale (1 $=$ not at all important; $4=$ essential) how important they believed specific library services to be.

Observational and interview data were collected to supplement the survey data. This [sic] data were gathered to gain a fairly accurate 
idea of how many people enter the library on a daily basis and to determine the reasons why patrons came to the library. "Naturalistic observations of HBLL patrons were...conducted, [regarding students' use of the library], followed by interviews... at random intervals throughout the day for one week." 12

The observations were conducted by library student assistants who watched selected patrons for about an hour. Observers noted what the patron was doing, in what area of the library, and what materials were being used. After the observation, the patrons were approached and asked if they would be willing to be interviewed briefly. Of the 176 patrons who were observed, 125 agreed to the interview. Patrons were asked three short questions: 1) their library affiliation, that is, BYU student or faculty, student from another institution, or community patron, 2) how long they planned to spend in the library, and 3) the purpose of their visit to the library.

\section{Results and Discussion}

Gate counts, circulation, and length of time in the building were broken out by university status, but re-shelving statistics, periodical usage and interlibrary loan were not. Use of interlibrary loan was reported only as numbers of items loaned or borrowed, however, statistics for the Faculty Document Delivery Service (filled rate) are reported in the article. 
Use of the library building

As mentioned earlier, libraries across the country were experiencing a decline in patrons, which translated into a decline in circulation and reference. For example, Julie Banks' study at Southeast Missouri State University's Kent Library in 1999 showed "a dramatic decrease in building traffic, circulation, OPAC searching, and reference transactions at Kent Library over time. It also shows that circulation, OPAC searching, and reference transactions have a strong dependence on building traffic." ${ }^{13}$

The Lee Library also had declining gate counts during the late 1990s. The trend turned upward in 2000 when gate count statistics showed a steady increase in patron visits to the library. Observations confirm that students are everywhere in the library. Study tables, with electrical and Internet wiring, are highly used. The three computer labs are packed, with students often waiting in line for the next available computer. A walk past the circulation desk at various times of day reveals a line of students waiting for circulation clerks to check their books out for them. There are always books to be reshelved on the various floors, especially at the end of each semester.

The average number of persons entering the Lee Library each day during the study was $10,871 .^{14}$ Table 1 shows the data for the years $2000-2002$.

<table 1 here>

Table 1. Library Traffic 2000-2004 
Source: Danny R. Olsen and Kristoffer B. Kristensen, Harold B. Lee Library Resource Usage Study, (Provo, UT: Brigham Young University, Office of Institutional Assessment and Analysis, 2002), 29.

The most popular times to visit the library were between 12:00 noon and 2:00 p.m., 2:00 and 4:00 p.m., and 6:00 and 9:00 p.m. BYU students comprised 93.7 percent of patrons, 29.3 percent of which were seniors, 29.3 percent were juniors, 19.3 percent were sophomores, 14.3 percent were freshman, and 2.9 percent were graduate students. Of the remaining 6.3 percent, 4.7 percent were visitors or other students, 1.3 percent were faculty members, with 0.4 percent not answering the question. The majority of these students surveyed reported that they spent between three to 11 hours per day in the library. Faculty time spent in the library was almost evenly split between five to 45 minutes and three to 11 hours.

\section{Use of Library Collections}

The OPA report showed the following results.

- Twenty-two percent of the approximately 2.2 million bound volumes available for circulation were checked out during the period of the study.

- Circulation totals were highest during the latter-half of fall semester, October through November, and winter semester, February through April. 
- Circulation by patron type, including faculty, over a three-year period revealed that students, employees, and non-BYU patrons most often checked out materials in (1) languages, literature, (2) religion, and (3) social sciences, economics, and business.

- Student circulation percentages by college showed the highest circulation rates for the colleges of humanities and religion, with items circulated focusing specifically on languages, literature, and religious education.

- Most periodicals are housed together in the periodicals room. Periodicals are divided into two sections: 1987-present and pre-1987. The 1987-present section contains approximately 9,092 titles, of which 305,996 periodicals were re-shelved during the calendar year 2001. The highest areas of use were the sciences periodicals, and followed by the social sciences, economics, and business periodicals. February-March and October-November were the greatest re-shelving times.

- Re-shelving data for items used in-house but not checked out indicated that the highest areas of use were: juvenile, Asian, and music collections, followed by social sciences, economics, and business collections, and lastly the humanities/religion collections.

- During the study, the number of faculty document delivery requests filled was 7,248. This represents both books and articles, indicating 
that faculty use the library from their offices to obtain needed materials.

Use of other library services

If the library is the heart of the university, what activities take place inside? To determine what students did when they came to the library and which services they considered most important, the HBLL survey asked about the most frequently-used library services and the most important services the library offered, breaking down the data by undergraduate and graduate students to determine if these two groups used the library differently (see table 2).

$<$ table 2 here>

Table 2. Most frequently used library services

Source: Data from Olsen \& Kristensen, 2002.

From these findings it is evident that undergraduate and graduate students use the library for different reasons. Undergraduate students tend to come to the library to study, to use the Internet for non-school related assignments, and to use the computer labs.

Graduate students tend to come to use the online catalog and electronic databases, possibly reflecting their emphasis on research (see table 3).

$<$ table 3 here>

Table 3. Most important library services 
Source: Data from Olsen \& Kristensen, 2002.

When asked what the most important library services were, the responses were again broken down by undergraduate and graduate students. Both undergraduate and graduate students placed emphasis on the same top two services- the online catalog search and checking out books.

Of interest was the fact that reference and instruction, two core library services, did not appear to be important nor frequently used by students. Instruction was rated as "somewhat important," and the frequency of use was reported as "once a semester." These findings could be due to the fact that the library's instruction activities take place primarily in first-year writing and advanced writing courses. Students enrolled in firstyear writing courses attend two library sessions, whereas those enrolled in advanced writing courses attend one library session. Some academic departments require a research methods course with a library instruction component, but it is not a widespread practice. Because faculty assume that they received library instruction as an undergraduate, graduate students receive instruction only if faculty specifically request it, or they seek out their subject librarian.

Reference/information assistance was eighth in the list of important services, and frequency of use was reported as "monthly." This could be explained by findings from the LibQual+TM survey covering the same time period as the OPA study. One of the findings in the 2001 LibQual+TM was that students desire to be self-sufficient in the library. They exhibit a general tendency to do whatever they can on their own and only come to the reference desk if they have exhausted all other alternatives. A second factor 
could be the differing focus of the two studies. LibQual+TM focused on user perceptions of minimum and desired service levels, whereas the OPA study looked at how students rated and used services.

The study revealed some differences between the self-reported and observed activities (see table 4). As Danny Olsen and Kristoffer Kristensen noted, "In all cases, students reported themselves engaging in activities less frequently than they were observed performing those same activities." ${ }^{15}$ The students were most accurate when they reported visiting the Family History Center, checking their e-mail, using the Learning Resource Center, sleeping/resting, and studying. They were least accurate when they reported routine activities such as using the computer, talking/visiting, using periodicals, and reading.

<table 4 here>

Table 4. Observed vs. self-reported behavior

Source: Data from Olsen \& Kristensen, 2002.

\section{Group Study Rooms}

Collaboration is a growing trend for student assignments, and the library provides one of the best places on campus for students to gather in a quiet room and study together. Many of these study rooms have white boards where students can teach one another, and some have Internet connections allowing students to use their laptop computers. During the fall of 1991, Althier Lazar conducted a study at the University of Pennsylvania concerning 
the people and the reasons involved in studying in groups. Lazar explained, "Students need to read and remember massive amounts of material. ... They struggled with the expectations of college writing...[and] are overwhelmed by major exams." ${ }^{16} \mathrm{He}$ determined from a small study group that the students'

study conversations served the intellectual, social, and emotional needs in profound ways. ...[Students] solved problems together, challenged each other, and shared strategies.... Students seemed to study collaboratively for subjects they believed were the most difficult. Courses that required quantitative problem solving, like calculus, were perceived as more difficult than courses in which reading and writing were the primary tasks. ${ }^{17}$

The use of the library's 39 group study rooms during the fall semester of 2001 ranged from 10 percent during the first week of September to highs of over 70 percent during the last two weeks of the semester. Usage was consistently around 60 percent during the middle of the semester. ${ }^{18}$ Of the students using the group study rooms, the largest percentage, 24.13 percent, were groups in the physical and mathematical sciences. Groups in family, home and social sciences accounted for 14.48 percent of users, followed closely by groups from the Marriott School of Management (business students) with 13.15 percent of the usage. Biology and agriculture groups (10.89 percent) and humanities groups (10.57 percent) rounded out the top five in terms of usage of group study rooms. The remainder of groups represented a variety of disciplines (see table 5). The OPA report supports Lazar's research, demonstrating that student groups using the 
study rooms were generally enrolled in the "harder subjects" such as the physical and mathematical sciences. The OPA report concluded that "the [library] continues to be a center of student learning as measured through the extensive use of group study rooms."19

$<$ table 5 here >

Table 5. Group study room usage Fall 2001

Source: Data from Olsen \& Kristensen, 2002.

\section{Electronic Resources}

The total number of hits on the BYU library Web site dramatically increased during this study from almost 15.7 million in 2001 to nearly 27.1 million in $2002 .^{20}$ Approximately 45 percent of all data requests occur within the library. ${ }^{21}$ This seems to mirror the growing trend of accessing the library remotely from on-campus computer labs or from student housing.

The Internet seems to have enabled a new type of student who browses the Web in search of quick and easy information. According to a recent study conducted by the Digital Library Federation and Outsell, Inc., 83 percent of faculty and students report that they go online when searching for information. ${ }^{22}$ Dubbed Millennials or the Net Generation, those who were born in 1982 or later, have grown up on the Internet and are comfortable using it as an information-retrieval mechanism. They use search engines such as Google or Yahoo on a daily basis to find information whenever and wherever they are. Students lead busy lives and want to find and use information quickly. Diana 
Oblinger states that "having grown up in a customer-service culture, today's students have a strong demand for immediacy and little tolerance for delays. They expect that services will be available $24 \times 7$ in a variety of modes (Web, phone, in person) and that responses will be quick." 23

Not only do students use Internet search engines, Amanda Spiteri asserts that "there is a growing mentality, particularly among the younger generation, that if it doesn't come up in an Internet search engine then it doesn't exist." ${ }^{24}$ Because so much information is available at the click of a button, many students today fail to investigate what additional resources libraries have to offer. Thomas Mann observes:

What is distinctive about libraries? The real strength of libraries lies in our ability to provide access, both now and in the long-term future, to important resources that cannot be tapped into from anywhere at anytime by anyone. ... These are the things we need to concentrate on, and they are much more important than coffee bars, meeting rooms, and cultural programs for justifying the maintenance of libraries as places. ${ }^{25}$

Indeed, it appears that the Lee Library continues to be the center of students' education. The OPA study found that BYU students, faculty, and staff continue to use the library for a variety of academic and social activities. The collections have a strong overall use, and the Internet supplements the physical collections by providing online access to the library's electronic collections. The physical building itself is highly used with its study tables, study rooms, and computer labs. 
Two Years Later

Two years after the OPA study (2004), the Lee Library is still heavily used-despite the anecdotal evidence we hear from students and faculty and via our chat service that they now access the library remotely rather than coming into the building. A walk around the library on any day reveals full study tables, lines outside computer labs and at circulation and reference desks. Students are filling group study rooms and overflowing into halls, lounge areas, and elevator alcoves — basically anywhere there is a bit of open space on the floor. To quantitatively assess the usage of the library, the authors had planned to compare statistics reported in the OPA study and statistics available from the latter part of 2002 through the end of 2004 but determined that without replicating the original study, which is not possible at this time, only some of the data could be compared. However, the available data will be presented with an analysis of usage patterns.

\section{Methodology}

During 2005, as this article was being written, the authors decided to collect additional data to see if the trends had changed in the years since the OPA study was done. The authors were not able to duplicate the OPA study but gathered the available comparable statistics from Web pages and other library departments. Usage, circulation, and reshelving statistics are routinely collected by the library's process improvement officer. Statistics were compiled for the years 2003-2004 and compared to those from 2000- 
2002. Group study room use statistics were obtained and compared to the 2000-2002 usage levels. However, the authors did not conduct a survey nor conduct naturalistic observations or interview students.

Results and Discussion

Use of the Library Building

With the advent of numerous online resources and easy accessibility, are students still coming to the library building? At BYU, the answer is yes. Average weekday patron visits to the Lee Library during the OPA study (2001-02) were 11,011 for 2001 and 11,294 for 2002 , with a two-year average of 11,152 . The data collected since 2002 show average weekday patron visits to the library during the two-year period from 2003-04 increased by 10.68 percent, with average daily counts of 12,098 and 12,588, respectively. The figures indicate a steady increase in the number of patrons entering the library on a daily basis. One factor that may have contributed to the increased gate count during this time was that from fall 2002 to fall 2003 the library provided space for nine academic classes held in the library auditorium with a seating capacity of 200. The 2003-04 statistics rose, however, even without the classes in the library. When gate count statistics are broken down by semester, the average weekday patron visits are higher during fall/winter semesters than during spring/summer terms, due to lower enrollment during spring/summer. 
Use of Library Collections

- Compared with the 1.4 million items circulated between September 1998 and September 2001, from September 2001 to September 2004 nearly 2.12 million items circulated. This translates into a 43 percent increase in the number of items checked out.

- Circulation by patron type for the years 2002-2004 was not available, but general circulation figures revealed that the materials most often checked out were in (1) languages, literature, (2) history and (3) social sciences, economics, and business. Whereas history replaced religion as the second category of items most circulated, the first and third categories remained the same.

- The authors were not able to calculate student circulation percentages by college, but according to the numbers for items checked out by call number, during the period of 2001-2004, the areas of literature, religion, humanities, and social sciences consistently showed the largest numbers of items circulated. ${ }^{26}$ This is consistent with the OPA findings that literature, humanities, and religion were the heaviest circulated items. The social sciences are a new addition, but overall, the later findings are consistent with the OPA report, showing little change in the subjects with heaviest circulation.

- Re-shelving data for items used in-house but not checked out during the OPA report period indicated that the highest areas of in-house use by patrons were the juvenile, Asian, and music collections, followed 
closely by the social sciences, economics, and business collections and, finally, the humanities and religion collections. Data collected since 2002 show a change; the humanities and juvenile collections are the most-used collections, followed by the social science and science collections.

- Faculty document delivery requests that were filled almost doubled from 7,248 in 2001-2002 to an average of 14,628 per year for the years 2002-2004. One reason for the large increase in service may be because, beginning in 2003, a brochure describing the service is now delivered to faculty once a semester.

$<$ table 6 here>

Table 6. Faculty Document Delivery Requests Filled 2001-2004

Source: Data from Harold B. Lee Library Faculty Delivery Service statistics.

Not only are students coming to the library building, they are also using the library collections both in-house and outside the library. The more recent data show a substantial increase in items circulated during the two years following the OPA study; however, the subjects with the heaviest circulation have changed very little, with one exception, the social sciences. Statistical data tracking the use of in-house items showed that humanities moved from being one of the less-used collections to being one of the most-used collections. The juvenile collection also remained one of the most-used 
collections. The social sciences collection remained in second place, and the science collection emerged as the third most-used collection, replacing religion.

Use of Other Library Services and Resources

\section{Group Study Rooms}

Group study rooms continue to be heavily used by students. An online reservation program for group study rooms was implemented in fall semester of 2002. Fall semester of 2002 showed a slight decrease in use to 58 percent from the 60 percent reported in the OPA report. However, fall semester of 2003 and 2004 both showed increased usage of 63 percent and 65 percent, respectively.

While spring/summer term usage is not reported here, when usage is broken out by semesters and terms, usage in fall/winter semesters is higher than usage in spring/summer terms; this is due to lower enrollments during spring/summer terms. One

finding that surprised the authors was that from 2003-2004, spring/summer term usage of group study rooms increased by 11.64 percent. This was surprising due to the fact that during both the 2003 and 2004 spring/summer terms, construction in the library made some group study rooms unavailable for use.

Who is using group study rooms? Group study room usage by discipline is presented in table 7 . While group study room usage is up, only one discipline, the business students from the Marriott School of Management, showed an increase over the years 2001-2004, rising from 14 percent to 32.88 percent usage. Two disciplines, physical and mathematical sciences and health and human performance groups, showed a 
decline in groups study room usage. All other disciplines both rose and fell over the three years. The top five disciplines - physical and mathematical sciences, family home and social sciences, Marriott School of Management (business), biology and agriculture, and humanities - accounted for a total of 73.22 percent of group study room usage in fall 2001. However, in spite of some declines in group study room usage by other disciplines, those same five disciplines accounted for 87.2 percent of group study room usage in fall 2004, demonstrating an increased use of group study rooms in the library.

$<$ table 7 here>

Table 7. Group study room usage Fall 2001-Fall 2004

Sources: Data from Olsen \& Kristensen, 2002; Harold B. Lee Library Group Study Room Reservation statistics.

\section{Electronic Resources}

Use of electronic resources is increasing in academic libraries across the country. However, due to the lack of standardized reporting methods, it is difficult to accurately determine the number of Web site hits and how many times database or other digital records are accessed. The OPA report discussed library Web page usage; but since the study was completed, the method employed to track Web page usage has changed significantly, making valid comparisons impossible. 
New Services

Since the OPA study was completed, there have been many changes in the library landscape that affect student usage. More and more resources are available online and technological developments have made remote access easier and more convenient. The establishment of computer labs across campus and in university housing, as well as the wiring of off-campus housing for Internet access has increased dramatically. Request forms, electronic submission of theses and dissertations, and desktop delivery of interlibrary loan articles are other services that the Lee Library has inaugurated in recent years. These combined changes make it easier for library resources and services to be accessed outside the building.

Despite not being able to replicate the original study, the Lee Library continues to scan the environment for new services to keep the library at the heart of the university. Administrators meet regularly with the Student Advisory Council to discuss needs and/or services that students are requesting. The Student Advisory Council "serves the BYU community by accurately representing student opinion to the administration, enhancing its ability to make informed decisions. ${ }^{27}$ The council is composed of 32 representatives from each college and various groups of students, such as freshmen, graduate students, international students, the multicultural and accessibility centers, ROTC, and the University Curriculum Council.

The requests generated from these discussions often have an impact on library usage (or services??) and strengthen the library as the center of learning. As a result of 
student requests, two new services - extended hours and an information commons - have been developed and put into operation since the OPA report.

\section{Extended Hours}

Students had requested extended hours during the last three weeks of the semesterwhich includes one week before reading days (days given to the students to prepare for final examinations), reading days, and finals' week when library usage is high. The library's reasons for offering extended hours were to provide students with extra study time, time to finish research projects, and open computer labs to facilitate completion of papers. During December 1-19, 2003, the library experimented with a pilot project keeping the library open two additional hours per day to see if students would use the library between midnight to 2:00 a.m. Moreover, the library wanted to determine how students would use the library during those hours, in order to provide the appropriate levels of staffing.

A memo from the library's process improvement specialist reported that three items were used to determine how students used the library during extended hours: body counts, reference and circulation transactions, and activity observations by library staff.

The total number of patrons [using] the library over the experimental period was 9,335 . This figure should be considered a liberal estimate since it is highly likely that many of the individuals in the library stayed through the entire two hours and would have been double counted. It is also probable to assume that a patron 
may have relocated to another part of the library after being counted once during a rover's rounds and then being counted again at a later point during that same round... or there may have been a substantial number of patrons already in the building before the beginning of the 2 hour extension. ...Patron traffic was heaviest during the 12 to 1 o'clock hour, with activity diminishing after that until closing. ${ }^{28}$

Activity observations indicated that patrons generally were engaged in educationrelated activities during the extended hours. During these hours, the periodicals room and the computer labs were the most heavily used areas in the library. The periodicals room is a favorite study area any time of day, and observations of students showed that most were using it as a study room rather than being in the room to use the periodicals. However, the average of reference transactions in periodicals and at general reference was about 67 transactions per hour during the extended hours. These figures are consistent with the number of reference and periodical transactions occurring during the 7:00 a.m. and 11:00 p.m. hours that the library is normally open. In contrast to normal hours, circulation transactions were low, but checkouts were consistently greater than at 7:00 a.m. ${ }^{29}$

These findings indicate that the library was primarily used as a study hall or computer lab during extended hours. This is consistent with the original assumptions that students would be using the extra hours to study, finish research projects, and complete papers. "Overwhelmingly, those involved with this experiment [a focus group of library employees on duty during the extended hours] felt it more than met expectations and 
should be continued. ... The advantage gained from a public relations standpoint exceeds any cost of having the building opened the additional hours." ${ }^{30}$ In the ensuing semesters since the pilot, extended hours have proven to be very popular among the students who come to the library, and these extended hours are now a regular service.

\section{Information Commons}

In response to the number of group presentations and collaborative projects being assigned by professors, the Lee Library added an information commons area to the library during November 2004. Tables with computers, scanners, and extra chairs were arranged to allow multiple students to gather around a computer workstation for the purpose of collaborating on assignments, research, presentations, and so on. In addition to the collaborative learning stations, the information commons area includes multimedia workstations, Macromedia stations, and two creative learning rooms (technologyenhanced group study rooms).

The workstations are loaded with a variety of application software including the full Microsoft Office, Macromedia, and Adobe suites as well as scanning and utility programs. The tools available on the multimedia stations enable students to work on "projects involving Web design, digital audio and video manipulation." ${ }^{31}$ Four workstations, created from repurposed book index tables, have small whiteboards attached to the rear of the tables enabling students to draw, sketch, diagram, figure, and so on, while sharing ideas. 
Equipment available for checkout in the information commons includes two camcorders, one still camera, tripods, and a digital voice recorder. "Creative Learning rooms provide students with additional technological tools to aid in their group study experience. Both rooms offer Information Commons Workstations, projectors and extra laptop ports. ${ }^{32}$ One room has a traditional group study whiteboard, and the other room offers the PolyVision Impulse LTX Multimedia Whiteboard System.

Additionally, the student publication lab relocated to a space adjoining the information commons, making it easier for students to receive help with papers they wish to submit for publication in various on-campus publications. A reference librarian, a computer support expert, and a multimedia expert are available to answer questions and assist students with projects.

Are students using the information commons? During peak periods, defined as 10:00 a.m. to 5:00 p.m. from the months of November through April, the computer reservations statistics for the information commons indicate over 90 percent usage nearly every day. The workstations and the creative learning rooms are most heavily used from Monday to Wednesday. Usage patterns show this area is heavily used near finals, with usage dropping during reading days, and picking up again during finals. Although daily use is generally the heaviest between Monday and Wednesday, use increases even on Thursday and Fridays near the end of fall and winter semesters. ${ }^{33}$

Students must reserve a workstation for use in the information commons by using their university NetID and password. An analysis of computer reservation statistics from February to April 2005 (statistics for the information commons were not separated from general information services computer use statistics until February 2005) shows that the 
total number of users, including one-time use and multiple-uses by the same patron, is consistently between 30-45 percent of the student population. Logins per user averaged 3.3 during the months reported. The average time a user spends on a workstation is 41 minutes. The 38 computers in the information commons averaged 433 logins per computer (see table 8).

\section{$<$ table 8 here>}

\section{Table 8. Information commons computer usage}

Note: Includes end of winter semester and beginning of spring term when enrollment is lower.

Source: Harold B. Lee Library Information Commons statistics.

Use of the information commons closely mirrors the use of other library resources. Peak use periods for reference, circulation, study rooms, and computer labs are highest from November through April, with November and March being the two highest months. Both the extended hours and the information commons are popular with students, but there is no data to confirm that students are coming to the library specifically to use these services. It is true that gate counts have increased, but currently there is no way to substantiate that the counts have increased as a result of adding these two services. Correlating gate count to new services is an area for further research.

\section{Conclusion}

The 2002 OPA report concluded that 
The HBLL continues to remain the "heart of the campus" for both faculty and students. Much of the academic and social life, for students in particular, centers in the HBLL. The collections, study tables and rooms, and computer labs were indicated by students as being central to their activities....The collection seems to be highly used and is central to the academic activities of BYU patrons. The circulation statistics and in-house use estimates indicate strong overall use of the collection. ...Although electronic access to the collections and resources is on the rise, these resources only seem to supplement the physical collection of the HBLL for patrons. ...Circulation and in-house use statistics have not dramatically shifted with the addition of electronic materials. ${ }^{34}$

Is the conclusion of the OPA report still applicable two years later? Does the Lee Library, both the building and the services, continue to remain at the center of a university education for both students and faculty, or has the virtual library replaced it? To definitively answer that question, the original study would have to be duplicated. However, our research shows a 10.68 percent increase in daily patron visits, a 43 percent increase in items circulated, a solid 5 percent increase in the usage of group study rooms, the information commons workstations usage at over 90 percent, and the popularity and use of extended hours. To us, these numbers are signs that the library building and its services play a significant role in the academic life of the BYU community. 
Continuing changes in the landscape of academia — such as use of course management systems, hybrid course development, increased digitization of materials, changes in scholarly communication patterns, distance education programs, and new uses for personal assistance devices - will challenge the library to develop new ways of meeting the changing needs of the faculty and students in order to remain central to the academic life of campus. However, Nicholas Basbanes summed it up best when he said, "Libraries will remain important to colleges and universities." ${ }^{35}$

Patricia A. Frade is a serials cataloger, Harold B. Lee Library, Brigham Young University, Provo, UT; she may be contacted via email at: pat_frade @ byu.edu.

Allyson Washburn is the distributed learning services librarian, Harold B. Lee Library, Brigham Young University, Provo, UT; she may be contacted via email at: allyson_washburn@byu.edu.

Notes

1. Chauncey Brewster Tinker, The Tinker Library: A Bibliographical Catalogue of the Books and Manuscripts collected by Chauncey Brewster Tinker; compiled by Robert F. Metxdorf (New Haven: The Yale University Library, 1959), vii.

2. Maureen Brunsdale, "From Mild to Wild: Strategies for Promoting Academic Libraries to Undergraduates," Reference \& User Services Quarterly 39, 4 (Summer 2000): 331-2. 
3. L. Jolley, "The Function of the University Library," Journal of Documentation 18, 3 (September 1962): 140.

4. Leo Clougherty et al., "The University of Iowa Libraries' Undergraduate User Needs Assessment," College and Research Libraries 59, 6 (November 1998): 576.

5. Danny R. Olsen and Kristoffer B. Kristensen, Harold B. Lee Library Resource Usage Study (Provo, UT: Brigham Young University, Office of Institutional Assessment and Analysis, 2002), 5.

6. Scott Carlson, "The Deserted Library," Chronicle of Higher Education (November16, 2001): A35-6.

7. Andrew Richard Albanese, "Deserted No More," Library Journal 128, 7 (April 15, 2003): 34 .

8. Ibid.

9. Steve Stanek, "Academic Libraries Thrive Amid Technology," Chicago Tribune, March 2, 2003.

10. Albanese, 34 .

11. Olsen and Kristensen, 5-6.

12. Ibid., 5 .

13. Julie Banks, "Does Building Traffic Affect Circulation, OPAC Searching, or Reference Desk Activity?" Library Computing 18, 4 (1999): 332.

14. Harold B. Lee Library, "Library Statistics," Brigham Young University, http://lib.byu.edu/stats.html (accessed March 30, 2006).

15. Olsen and Kristensen, 39. 
16. Althier M. Lazar, "Who is Studying in Groups and Why?" College Teaching 43, 2 (Spring 1995): 61.

17. Ibid., 62 .

18. Olsen and Kristensen, 6, 27.

19. Ibid., 28.

20. Harold B. Lee Library.

21. Olsen and Kristensen, 6.

22. Daniel Greenstein, "Library Stewardship in a Networked Age," in Access in the Future Tense, CLIR Reports, publication 126 (Council on Library and Information Resources, April 2004), http://www.clir.org/pubs/abstract/pub126abst.html (accessed March 30, 2006).

23. Diana Oblinger, "Boomers, Gen-xers \& Millennials: Understanding the New Students," Educause Review 38, 4 (July/August 2003): 40.

24. Doug Henschen, "Add Value to Beat 'Googlization,'" Intelligent Enterprise (February 1, 2005), http://www.intelligenteai.com/showArticle.jhtml?articleID=57702079 (accessed March 30, 2006).

25. Thomas Mann, "The Importance of Books, Free Access, and Libraries as Places - and the Dangerous Inadequacy of the Information Science Paradigm," The Journal of Academic Librarianship 27, 4 (July 2001): 274-5.

26. Harold B. Lee Library.

27. BYU Student Service Association, "What is the Student Advisory Council?" Brigham Young University, 
http://byusa.byu.edu/Student_Advisory_Council_What_is_the_Student_Advisor y_Council_(SAC)_qq.htm (accessed March 31, 2006).

28. Brian Roberts, process improvement specialist, e-mail memo to the author, January 19, 2004.

29. Ibid.

30. Ibid.

31. Harold B. Lee Library, Information Commons, Brigham Young University. http://lib.byu.edu/departs/gen/ic/index.html (accessed March 30, 2006).

32. Harold B. Lee Library, Creative Learning Rooms, http://lib.byu.edu/departs/gen/ic/rooms.html (accessed March 30, 2006).

33. Jonathan Mecham, computer support technician, e-mail to authors, June 14, 2005. 34. Olsen and Kristensen, 7.

35. Stanek, 1. 
Table 1

Library Traffic $2001-2002$

\begin{tabular}{lrrrrrrrrrrrr}
\hline & Jan & Feb & Mar & Apr & May & Jun & Jul & Aug & Sep & Oct & Nov & Dec \\
\hline $\mathbf{2 0 0 0}$ & & & & & 4620 & 5013 & 5036 & 6599 & 14252 & 14713 & 12689 & 14390 \\
$\mathbf{2 0 0 1}$ & 12699 & 14000 & 14000 & 11655 & 5425 & & 5310 & 5333 & 14345 & 15379 & 14321 & 14000 \\
$\mathbf{2 0 0 2}$ & 13334 & 11702 & 14000 & 13678 & 5357 & 7310 & 5332 & 5287 & 16000 & 15701 & &
\end{tabular}

Source: Danny R. Olsen and Kristoffer B. Kristensen, Harold B. Lee Library Resource Usage Study, (Provo, UT: Brigham Young University, Office of Institutional Assessment and Analysis, 2002), 29. 


\section{Table 2}

Most frequently used library services

\begin{tabular}{|c|c|c|c|}
\hline & Undergraduates & & Graduates \\
\hline 1. & Spaces or tables to study & 1. & Library catalog \\
\hline 2. & Internet use & 2. & Electronic databases \\
\hline 3. & Computer labs & 2. & Internet use \\
\hline 4. & Library catalog & 4. & Spaces or tables to study \\
\hline & Courtesy phones & & Copy machines/centers \\
\hline
\end{tabular}

Source: Data from Olsen \& Kristensen, 2002. 
Table 3

Most important library services

Undergraduates Graduates

1. Ability to check out books 1. Library catalog and other materials

2. Ability to search the online 2. Ability to check out books catalog and other materials

3. Spaces/tables to study items 3. Electronic databases brought by students

4. Electronic databases or index 4. Copy machines/centers searches

5. Spaces/tables to study items 5. Access to periodicals found in the library

Source: Data from Olsen \& Kristensen, 2002. 


\begin{tabular}{rcc}
\hline \multicolumn{3}{l}{ Table $\mathbf{4}$ Observed vs. self-reported behavior } \\
\hline & Observed Data & Self Reported Data \\
\hline Study & $50.0 \%$ & $48.5 \%$ \\
Computer use & $33.7 \%$ & $10.5 \%$ \\
Reading & $29.3 \%$ & $12.6 \%$ \\
Talking/Visiting & $23.6 \%$ & $3.7 \%$ \\
Periodicals & $22.6 \%$ & $2.7 \%$ \\
Writing & $8.6 \%$ & $4.8 \%$ \\
Sleep/Resting & $4.1 \%$ & $2.1 \%$ \\
Lockers & $3.5 \%$ & $0.7 \%$ \\
Email & $3.0 \%$ & $2.3 \%$ \\
LRC & $2.5 \%$ & $1.5 \%$ \\
Family History & $1.5 \%$ & $0.7 \%$
\end{tabular}

Source: Data from Olsen \& Kristensen, 2002. 
Table 5

Group study room usage Fall 2001

\begin{tabular}{rc}
\hline Discipline & Fall 2001 \\
\hline Biology \& Agriculture & $10.89 \%$ \\
Education & $0.52 \%$ \\
Engineering \& Technology & $8.55 \%$ \\
Family, Home \& Social Sciences & $14.48 \%$ \\
Fine Arts \& Communications & $5.60 \%$ \\
Health \& Human Performance & $1.01 \%$ \\
Humanities & $10.57 \%$ \\
International \& Area Studies & $7.35 \%$ \\
Marriott School of Management & $13.15 \%$ \\
Physical \& Mathematical Science & $24.13 \%$ \\
Religious Education & $3.75 \%$
\end{tabular}

Source: Data from Olsen \& Kristensen, 2002. 


\section{Table 6}

Faculty Document Delivery Requests Filled 2001-2004

\begin{tabular}{lllllllllllllll}
\hline & Sep & Oct & Nov & Dec & Jan & Feb & Mar & Apr & May & Jun & Jul & Aug & Total \\
2001-2002 & 551 & 747 & 725 & 410 & 469 & 563 & 556 & 680 & 728 & 674 & 736 & 409 & 7248 \\
$\mathbf{2 0 0 2 - 2 0 0 3}$ & 1212 & 1256 & 898 & 833 & 975 & 945 & 950 & 1062 & 192 & 1153 & 1060 & 785 & 12321 \\
$\mathbf{2 0 0 3 - 2 0 0 4}$ & 1168 & 1229 & 771 & 898 & 1265 & 1910 & 1951 & 1101 & 1429 & 1626 & 1555 & 1493 & 16396 \\
\end{tabular}


Table 7

Group study room usage Fall 2001 - Fall 2004

\begin{tabular}{lllll}
\hline Subject & Fall 2001 & Fall 2002 & Fall 2003 & Fall 2004 \\
\hline Biology \& Agriculture & $10.89 \%$ & $14.00 \%$ & $8.01 \%$ & $9.17 \%$ \\
Education & $0.52 \%$ & $1 \%$ & $0.92 \%$ & $1.20 \%$ \\
Engineering \& Technology & $8.55 \%$ & $1 \%$ & $2.37 \%$ & $1.95 \%$ \\
Family, Home \& Social Science & $14.48 \%$ & $19.00 \%$ & $17.03 \%$ & $15.26 \%$ \\
Fin Arts \& Communications & $5.60 \%$ & $4.00 \%$ & $4.41 \%$ & $4.67 \%$ \\
Health \& Human Performance & $1.01 \%$ & $1.00 \%$ & $0.80 \%$ & $0.66 \%$ \\
Honors Program & $\mathrm{NA}$ & $\mathrm{NA}$ & $0.56 \%$ & $0.94 \%$ \\
Humanities & $10.57 \%$ & $19.00 \%$ & $16.31 \%$ & $15.25 \%$ \\
International \& Area Studies & $7.35 \%$ & $\mathrm{NA}$ & $0.30 \%$ & $0.41 \%$ \\
Law School & $\mathrm{NA}$ & $2.00 \%$ & $0.20 \%$ & $0.28 \%$ \\
Lee Library & $\mathrm{NA}$ & $\mathrm{NA}$ & $0.00 \%$ & $0.03 \%$ \\
Marriott School Of Management & $13.15 \%$ & $14.00 \%$ & $29.92 \%$ & $32.88 \%$ \\
Nursing & $\mathrm{NA}$ & $1.00 \%$ & $0.30 \%$ & $0.23 \%$ \\
Open Major & $\mathrm{NA}$ & $\mathrm{NA}$ & $0.13 \%$ & $0.24 \%$ \\
Physical \& Mathematical Science & $24.13 \%$ & $21.00 \%$ & $15.73 \%$ & $14.64 \%$ \\
Religious Education & $3.75 \%$ & $3.00 \%$ & $3.02 \%$ & $2.19 \%$
\end{tabular}

Sources: Data from Olsen \& Kristensen, 2002; Harold B. Lee Library Group Study Room Reservation statistics. 
Table 8

Information Commons Computer Usage

\begin{tabular}{rrrr}
\hline $\mathbf{2 0 0 5}$ & Feb & Mar & Apr \\
\hline Unique Logins & 4,859 & 5,338 & 4,764 \\
Repeat Users & 11,354 & 13,572 & 9,429 \\
Total & 16,213 & 18,910 & 14,193 \\
Logins per User & 3.3 & 3.5 & 3.0 \\
Average Time Used min & 40 & 42 & 42 \\
Logins per Machine & 427 & 498 & 373.5
\end{tabular}

Note: Includes end of Winter Semester and beginning of Spring Term when enrollment is lower. Source: Harold B. Lee Library Information Commons statistics. 